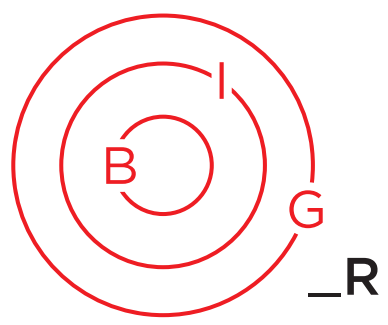

ESSAY

SPECIAL ISSUE

\title{
Governance in Imperial County and Mexicali at the U.S.-Mexico Border during the COVID-19 Pandemic
}

\author{
Kimberly Collins *
}

The COVID-19 pandemic has greatly impacted the lives of those living in the United States-Mexico border. From the Imperial Valley-Mexicali region, along the CaliforniaBaja California border, we find two interesting cases in public management that were impacted by the border population-medical care and informal importation of consumer goods. A lack of federal policy and guidance to improve the quality of life for people in the region leads us to rethink the role of governments and governance in the border region.

\section{Introduction}

The border region of Imperial County in southern California, United States, and the city of Mexicali in northern Baja California, Mexico, is located in the desert region of the two adjoining states. The region is just east of the coastal and metropolitan San Diego County and Tijuana/Rosarito/Tecate but a world away in ability to cope with the COVID-19 crisis. The same set of rules and regulations govern all of the communities along the California-Baja California border, yet this crisis has brought to light inequities along the border in terms of resources, ability of

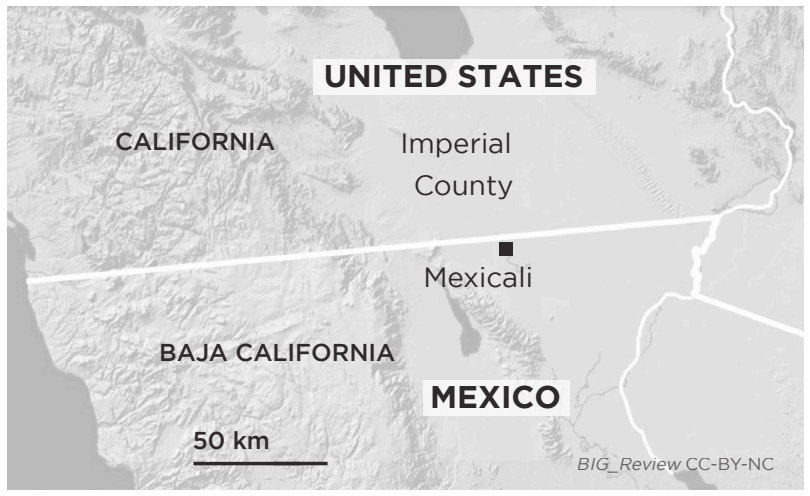

local governments to manage the public health in the region, and the role of national governments in cross-border relations.

The reader should recall that the response by both the federal governments in the United States and Mexico was delayed and insufficient to provide the needed resources, information, and aid to local communities. When learning of the pandemic, the messaging from President Donald Trump of the United States was that "everything was 'under control' and the virus would just 'disappear' in the warmer months" (Steven and Tan 2020; Superville and Seitz 2020).

A very similar situation occurred in Mexico. The Mexican President's initial response was to encourage Mexicans "to go to fiestas, eat in restaurants, and go out shopping" and he displayed "pictures of saints as protection against COVID-19" (Felbab-Brown 2020). Both nations were subsequently hit hard by the virus, with the U.S. leading the way in the number of cases and deaths. In July of 2020, there were more than 434,000 people infected with COVID-19 in Mexico and 47,472 deaths throughout Mexico. In the U.S., official data shows more than 4.6 million cases, and 154,912

\footnotetext{
* Kimberly Collins, PhD, Professor of Public Administration Executive Director of Leonard Transportation Center, California State University. Contact: kimberly@csusb.edu http://www.csusb.edu/ltc www.linkedin.com/in/Prof-kimberly-collins
} 
deaths (New York Times 2020a and 2020b). There has been a lack of federal leadership in providing a vision for managing this pandemic with inconsistent messaging, poor handling of supply chains of medical supplies, lack of testing, and hospitals struggling to meet the demands.

As the border is a federal zone, the absence of federal leadership adds a level of difficulty for those who live on both sides. It also led to the subnational governments (states, counties, and municipalities) taking an active role in managing the crisis. This created an uncoordinated response at times, within the countries and across the borders. In the San Diego-Tijuana region, local leaders discussed how the government response was slow, but the ability of the non-profit sector to step up and help was tremendous. In the Imperial Valley and Mexicali region, this was not the same since local leadership and humanitarian non-profit organizations were weaker.

A major joint federal decision was to limit the number of people crossing the border to only essential trips and trade beginning March 21. The tentative date to fully reopen the border has been moved a number of times and is currently set for November 21, but unless the number of cases diminishes, this date could be extended. The restrictions applied to non-essential travel (by non-citizens) and movement of goods. Essential travel included crossing for work, education, or medical reasons. To highlight the impacts on the travel across the region, the San Diego Association of Governments compared the April 2019 and 2020 data for the California-Baja California ports of entry. It showed the monthly average pedestrian crossings were down $76 \%$; personal vehicle traffic down by $53 \%$; and truck crossings were down 26\% (SANDAG 2020).

A point of confusion and discussion early in the pandemic was how to define essential business. Even with 25 years of a free trade agreement, no standardization was created on what would be considered essential and non-essential businesses in each country leading to disruptions in the supply chain. This led to more than 300 U.S. CEOs sending a letter to Mexico's president requesting the country align the definition of essential industries with the standards provided by the U.S. Department of Homeland Security. The Mexican government responded by opening previously nonessential businesses.

A U.S. federal decision that was detrimental to many people living in the border was the temporary closure of federal offices managing visas and trusted traveler programs. Many border residents had their lives in limbo, unable to access U.S. government offices for documents required to cross the border. It is expected that these offices will reopen once the pandemic has ended, but the closures resulted in a large amount of uncertainty and anxiety from this decision.
Even with these restrictions, U.S. citizens and permanent residents were still able to cross without restrictions, as long as it was considered essential travel. This limitation on travel has hurt local border businesses, but it has provided insight into the connections for people that bridge the border. Tens of thousands continue to cross daily as it is their legal right and also a necessity.

The COVID-19 pandemic has illuminated and exacerbated social problems within the United States and Mexico, and these have compounded at the border. The following sections of this paper will look at the impact on Imperial Valley-Mexicali region, looking at two specific cases-hospital capacity and the informal importation of beer into Mexicali. It will then provide some general concluding thoughts for moving regional governance into the 21st century.

\section{Managing Regional Consequences from COVID-19}

Two prominent cases speak to the handling of the virus at the Imperial Valley-Mexicali border region. The first has to do with the impact on Imperial Valley hospitals and the second has to do with the question of what is considered essential, particularly regarding the informal importation of beer. These might seem like two seemingly different issues, but have much to do with the local connections of the people and economy, and the place of government oversight in the movement of people and goods across the border.

\section{A crisis in medical care on the U.S. side of the border}

Imperial County had one of the highest percentages of COVID-19 cases in California. The county had 9,409 confirmed cases with 220 deaths as of August 1 (Imperial County Public Health Department 2020; California Department of Public Health 2020). Mexicali had 7,142 confirmed cases and 1,251 deaths. More people were treated and recovered in Imperial, but there were also more cases than in Mexicali, even though there were six times as many people living in Mexicali than Imperial.

At the beginning of the crisis there were many suppositions by locals on why the number of cases had been so high in Imperial and who brought the virus first to the region. At the time of writing, the county government was specific that the high number of cases was because of Mexicali and people coming across the border for medical care. When Mexicali hospitals were unable to admit any more patients in May, they were sent to Imperial County. There were reports that by early June patients were being transferred every two to three hours across the border. Before the pandemic, this number was 17 for an entire month (Jordan 2020). Officials from El Centro Regional Medical Center in 
Imperial County announced on May 19 that they would no longer be accepting COVID-19 patients in their emergency room. Since that time, more than 500 patients were air lifted out of county to other hospitals throughout California. It was likened to a warzone with helicopters coming and going from the hospital's rooftop helipad. Additionally, it should be noted that 60 employees of the El Centro Regional Medical Center lived in Mexicali and commuted across the border to work (Shih Bion 2020).

This medical situation shows the strong connections among the people living on either side of the border. People living in the region have always used medical providers on either side of border for a multitude of reasons. This movement of people to access healthcare has been reinforced by institutions on both sides. For just a couple of examples of the work done, see: CollinsDogrul (2006); Ruiz-Beltran, and Kamau (2001); and Davidhizar and Bechtel (1999). What added to the health crisis in these two valleys was the number of people with pre-existing cases of asthma and other medical conditions such as diabetes and obesity with notoriously bad air quality and high rates of poverty.

\section{Informal consumer imports and the border wait}

On June 27th, the mayor of Mexicali began to implement checkpoints at the two border crossings coming south into the city. The first time this was done, there was little communication with its closest neighbor, the small city of Calexico, which created a seven-to-eight hour wait at the border. These checkpoints were justified as the city stated many residents of Imperial Valley continued to travel to Mexicali to visit family and socialize. There was a fear they were bringing the virus with them.

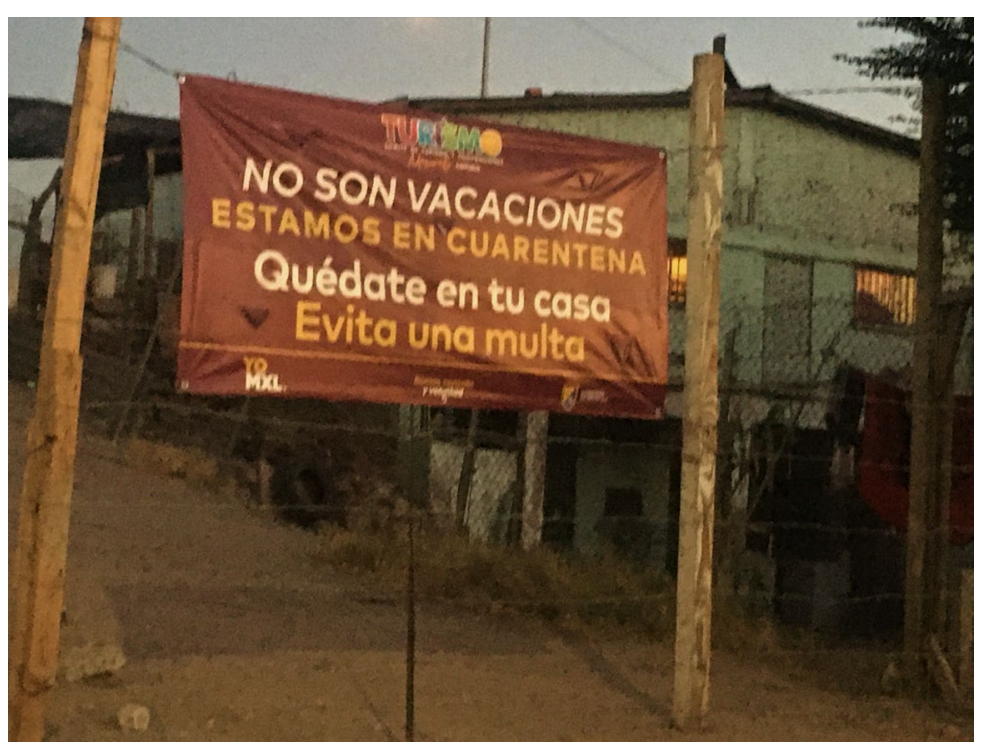

Figure 1. Sign by the Baja California Tourism Office, near the Mexicali Border, requesting people not travel. It reads: "This is not vacation time. We are under a quarantine. Stay in your home. Avoid a ticket”.
At the checkpoint, the officials checked peoples' temperatures, and also if there was any merchandise in their cars, such as beer. Any beer that was over the permitted limit for import was confiscated by authorities. It was therefore reasoned that these checkpoints were also intended to stop the informal importation of beer (Montenegro Brown 2020).

This problem goes to the decision taken by governments on what was considered essential business and what was not. In Mexico, the production and sale of alcohol was not an essential business, but Mexicali has the highest beer consumption per capita in the nation. The mix of these two factors led people and small entrepreneurs to import beer from the Imperial Valley and sell at times for triple its retail value. So, for example, a case of beer that sold for $\$ 20$ in California stores was sold for as much as $\$ 60$ in Mexicali. The government stepped in and tried to stop this flow of alcohol and caused long lines to cross south.

The informal movement of goods is not a new line of research or something new to the region (Buehn and Eichler 2009). This type of commerce has been happening for years and it has been linked to agreements at the national level. So, in this case, the disagreement over what was essential during the pandemic was an issue at both the national and local levels. In other words, national disagreements played out at the border, impacting local quality of life.

\section{Border Management During Crisis and Thoughts for the Future}

These border management problems during a time of crisis lead a researcher to question the effectiveness of the high-level conversations and collaboration between the U.S. and Mexico since the last major national security crisis, September 11,2001 . It is clear that the current binational management regime based on the federal government's supremacy is not improving the lives of the more than 14 million people in the region.

Are there other possibilities for public management, governance, and decision making at the border? The border states are highly engaged in policy fora such as health, transportation, environmental protection, natural resource protection, emergency response, and education. Their role in each is based within their jurisdictions, and they work well together to get things done. This is seen in their response to COVID-19. The local governments took the lead to keep residents safe and provide a response to the pandemic. The problem is that it is difficult for governments to work across the border to provide solutions. 
Borders in Globalization Review | Volume 2 | Issue 1 | Fall/Winter 2020 Collins, "Governance in Imperial County and Mexicali at the U.S.-Mexico Border"

The pandemic has provided an opportunity to rethink governance. For more discussion on regional crossborder management, see Collins (2017) and BrunetJailly (2004). Those working in the border region should view the COVID-19 crisis as an opportunity to propose new modes of government. Values should be based in human needs and solving problems of residents and taxpayers. Without innovative solutions to 21st-century challenges, the border region may be consigned to increasing marginalization, impoverishment, and inequity.

\section{Works Cited}

Brunet-Jailly, Emmanuel. 2013. "Power, Politics and Governance of Borderlands” in P. Gilles, H. Koff, C. Maganda, and C. Schulz (eds.) Theorizing Border Analyses of Power Relationships. Belgium: P.I.E. Peter Lang.

Buehn, Andreas, and Stefan Eichler. 2009. "Smuggling Illegal versus Legal Goods across the U.S.-Mexico Border: A Structural Equations Model Approach". Southern Economic Journal 76(2): 328-350. https://www.jstor.org/ stable/27751470

California Department of Public Health (2020). COVID-19 Updates. Available: http://cdph.ca.gov/Programs/CID/ DCDC/Pages/Immunization/ncov2019.aspx\#

Collins, Kimberly. 2017. "Globalization, Democracy, and Public Space: The Case of the U.S.-Mexican Border Region". Journal of Public Management \& Social Policy 24(1): 53-70. Available: https://digitalscholarship.tsu.edu/jpmsp/ vol $24 /$ iss $1 / 5$

Collins-Dogrul, Julie. 2006. "Managing US-Mexico "border health': An organizational field approach". Social Science \& Medicine 63: 3199-3211. https://doi.org/10.1016/j. socscimed.2006.07.031

Davidhizar, Ruth, and Gregory A. Bechtel. 1999. "Health and Quality of Life Within Colonias Settlements Along the United States and Mexico Border". Public Health Nursing 16(4): 301-306. https://doi.org/10.1046/j.1525-1446.1999.00301.x

Felbab-Brown, Vanda. 2020. "AMLO's feeble response to COVID-19inMexico". Brookings(March30).Available:http:// brookings.edu/blog/order-from-chaos/2020/03/30/ amlos-feeble-response-to-covid-19-in-mexico
Imperial County Public Health Department (2020). "COVID-19". Available: http://www.icphd.org/ health-information-and-resources/healthy-facts/ covid-19/

Jordan, Miriam. 2020. "Coronavirus Jumps the Border, Overwhelming Hospitals in California. The New York Times (June 7). Available: https://www.nytimes. com/2020/06/07/us/coronavirus-border-mexico-california-el-centro.html

Montenegro Brown, Richard. 2020. "'No Hay Cerveza' for Mexicali Residents Looking to Calexico Duty-Free Shops for Their Fix". Calexico Chronicle. (May 7). Available: https://calexicochronicle.com/2020/05/calexico-local-news/no-hay-cerveza-for-mexicali-residents-lookingto-calexico-duty-free-shops-for-their-fix/

New York Times. 2020a. "Mexico Coronavirus Map and Case Count" (August 2). Available: https://www.nytimes.com/ interactive/2020/world/americas/mexico-coronavirus-cases.html

New York Times. 2020b. "United States Coronavirus Map and Case Count" (August 2). Available: https://www.nytimes. com/interactive/2020/us/coronavirus-us-cases.html

Ruiz-Beltran, Martin, and Jimmy K. Kamau. 2001. "The SocioEconomic and Cultural Impediments to Well-Being Along the US-Mexico Border". Journal of Community Health 26(2): 123-132.

San Diego Association of Governments (SANDAG). 2020. San Diego Forward: A Bold New Transportation Vision. Comprehensive Multimodal Corridor Plans (June 26). Available: https://www.sandag.org/uploads/meetingid/ meetingid_5410_27686.pdf

Shih Bion, Xenia. 2020. "Coronavirus Doesn't Recognize Man-Made Borders." California Health Care Foundation (June 22). Available: https://www.chcf.org/blog/ coronavirus-doesnt-recognize-man-made-borders/

Stevens, Harry, and Shelly Tan. 2020. "From 'It's going to disappear' to 'WE WILL WIN THIS WAR'" Washington Post (March 31). Available: https:// www.washingtonpost.com/graphics/2020/politics/ trump-coronavirus-statements/

Superville, Darlene, and Amanda Seitz. 2020. "Trump defends disproved COVID-19 treatment". Associated Press (July 28). Available: http://apnews.com/80130998284858a7b7 3c997e76677137 